\title{
Social equity in governance of ecosystem services: synthesis from European treeline areas
}

\author{
Simo Sarkki ${ }^{1,2, *}$, Mikko Jokinen ${ }^{3}$, Maria Nijnik ${ }^{4}$, Lyudmyla Zahvoyska ${ }^{5}$, \\ Eleni M. Abraham ${ }^{6}$, Concepción L. Alados ${ }^{7}$, Chloe Bellamy ${ }^{8}$, \\ Svetla Bratanova-Dontcheva ${ }^{9}$, Karsten Grunewald ${ }^{10}$, Jozef Kollar ${ }^{11}$, Ján Krajč $\mathbf{~}^{12}{ }^{\text {, }}$ \\ Apostolos P. Kyriazopoulos ${ }^{13}$, Nicola La Porta ${ }^{14,15}$, Antonio T. Monteiro ${ }^{16}$, \\ Jose Munoz-Rojas ${ }^{4}$, Taras Parpan ${ }^{17}$, Louise Sing ${ }^{8}$, Mike Smith ${ }^{8}$, \\ Marja-Liisa Sutinen ${ }^{18, \mp}$, Anne Tolvanen ${ }^{19}$, Tetiana Zhyla ${ }^{5}$ \\ ${ }^{1}$ Cultural Anthropology, Faculty of Humanities, PO Box 1000, 90014 University of Oulu, Finland \\ ${ }^{2}$ Thule Institute, PO Box 7300, 90014 University of Oulu, Finland \\ ${ }^{3}$ Natural Resources Institute Finland, Kolari Office, Muoniontie 21 A, 95900 Kolari, Finland \\ ${ }^{4}$ The James Hutton Institute, Craigiebuckler, Aberdeen AB15 8QH, United Kingdom \\ ${ }^{5}$ Institute of Ecological Economics, Ukrainian National Forestry University, Generala Chuprynky Str. 103, 79057 Lviv, Ukraine \\ ${ }^{6}$ Aristotle University of Thessaloniki, 54006 Thessaloniki (236), Greece \\ ${ }^{7}$ IPE-CSIC, Avda. Montañana 1005, 50080 Zaragoza, Spain \\ ${ }^{8}$ Forest Research, Northern Research Station, Roslin, Midlothian EH25 9SY, United Kingdom \\ ${ }^{9}$ Institute of Biodiversity and Ecosystem Research,Bulgarian Academy of Sciences, Ecosystem Research Division, \\ 2 Gagarin Street, 1113 Sofia, Bulgaria \\ ${ }^{10}$ Leibniz-Institut für ökologische Raumentwicklung (IÖR) e.V., Weberplatz 1, 01217 Dresden, Germany \\ ${ }^{11}$ Institute of Landscape Ecology of the Slovak Academy of Sciences, Štefánikova 3, 81499 Bratislava, Slovak Republic \\ ${ }^{12}$ Trstené 59, 03221 Bobrovec, Liptovský Mikuláš, Slovak Republic \\ ${ }^{13}$ Democritus University of Thrace, Department of Forestry and Management of the Environment and Natural Resources, \\ 193 Pantazidoustr., 68200 Orestiada, Greece \\ ${ }^{14}$ Research and Innovation Centre, Fondazione Edmund Mach (FEM), Via E. Mach 1, 38010 S. Michele all'Adige, Trento, Italy \\ ${ }^{15}$ MOUNTFOR Project Centre, European Forest Institute (EFI), Via E. Mach 1, $38010 \mathrm{~S}$ Michele all'Adige, Trento, Italy \\ ${ }^{16}$ Research Center on Biodiversity and Genetic Resources (CIBIO), Rua Padre Armando Quintas, 4485-661 Vairão, Portugal \\ ${ }^{17}$ Ukrainian Research Institute of Mountain Forestry, 31 Hrushevskoho Street, 76018 Ivano-Frankivs'k, Ukraine \\ ${ }^{18}$ Natural Resources Institute Finland, Eteläranta 55, 96300 Rovaniemi, Finland \\ ${ }^{19}$ Natural Resources Institute Finland, Paavo Havaksen tie 3, 90570 Oulu, Finland
}

\begin{abstract}
Achieving social equity among local stakeholders should be a key objective for ecosystem service (ES) governance in Europe's ecologically fragile treeline areas. The ES literature tends to be biased towards distributional equity and market-based instruments when assessing social equity of ES governance. In this study, we analyze a wide range of social equity procedures that have been applied in Europe, using 11 synthesized case studies of governance-related challenges and 75 proposals for governance enhancement from 8 European countries provided by researchers with expertise on treeline area governance. The proposals were grouped by inductive clustering into 10 procedural or distributional equity-related policy recommendations: (1) increase stakeholder collaboration, (2) balance interactions between horizontal and vertical governance levels, (3) increase ES education, (4) use science to guide decisions, (5) start collaboration at an early stage, (6) enhance transparency, (7) aim to mitigate negative impacts, (8) use an ES approach to identify synergistic goals for governance, (9) enhance balanced multi-functional land use, and (10) use market-based instruments to balance benefits and costs deriving from governance decisions. Finally, we discuss 5 more general proposals on how regulatory and market-based approaches could be linked to enhance both procedural and distributional equity of treeline area governance.
\end{abstract}

KEY WORDS: Governance of ecosystem service - Stakeholders $\cdot$ Land use Climate change · Social equity $\cdot$ Multifunctional landscapes $\cdot$ Altitudinal/latitudinal treeline

*Corresponding author: simo.sarkki@oulu.fi

${ }^{\ddagger}$ Deceased

${ }^{\S}$ Advance View was available online February 7, 2017
(C) The authors 2017. Open Access under Creative Commons by Attribution Licence. Use, distribution and reproduction are unrestricted. Authors and original publication must be credited. 


\section{INTRODUCTION}

\subsection{Social equity of ecosystem service (ES) governance in treeline areas}

Currently, a key environmental problem with social equity implications is the unbalanced use of ecosystem services (ESs), which undermines the sustainability and resilience of ecosystems (MA 2005). ES governance is one way to manage and ease these problems (Primmer et al. 2015). ES governance refers to the decisions and governance instruments (e.g. regulatory policies and market-based instruments) that aim to manage the use of ESs, but also engage and monitor relevant ES users. Furthermore, ES governance takes into account different actors and networks that influence the formulation and implementation of policy decisions and the impacts of those decisions on different stakeholders (Pahl-Wostl 2009). Therefore, ES governance has social outcomes and the potential to regulate, incentivize and encourage stakeholders towards sustainable behavior (Hauck et al. 2013).

This study focuses on the social equity of ES governance in European treeline areas. Social equity has been distinguished from social justice, equality or fairness: equity is always relative and context specific, and requires that marginal groups should be favored with affirmative governance actions (McDermott et al. 2013).

We chose European treeline areas to study the social equity of ES governance because they can be considered as marginal rural areas, justifying affirmative governance measures to support local stakeholders. This has been recognized for example by European Cohesion Policy, that takes into account particular challenges and opportunities for mountainous areas (Gløersen et al. 2016). Risks imposed by climate change are most acute in treeline areas, and land use may have negative impacts on fragile treeline ecosystems (Huber et al. 2013). Treeline areas are sensitive to climatic fluctuations and consequently useful indicators of climate change (Kullman \& Øberg 2009). As tree growth is constrained by harsher environmental conditions with increasing altitude or latitude (Körner, 2012), the altitudinal or latitudinal forest- and tree-limits within the treeline areas may show differentiated responses to climate change (Hofgaard et al. 2013).

\subsection{Procedural and distributional equities}

As examined here, social equity of ES governance has 2 dimensions: procedural and distributional (Mc-
Dermott et al. 2013, Pascual et al. 2014). Procedural equity is about equipping certain stakeholder groups with tools and possibilities to achieve desired level of impact on decision making via facilitating the collaboration processes. Distributional equity is about fair distribution of benefits, burdens and risks, such that those who bear the risks and burdens also receive the most benefit (McDermott et al. 2013).

The themes related to procedural equity of the ES decision-making processes addressed in this study include transparency and openness of the ES related decision-making processes for local people (Heikkinen et al. 2010); problems relating to stakeholders' ability to take part in ES decision-making processes (Reed 2008); conflict resolution measures for enhancing relationships between the stakeholders (Agrawal \& Gibson 1999, Redpath et al. 2013); enhancement or establishment of decision-making forums linking governance levels, from local to global (Jordan 2000, Rauschmayer et al. 2009, Ostrom 2010); transdisciplinarity, linking local stakeholders to knowledge production and encouraging a holistic view on a particular issue that informs governance (Sarkki et al. 2013); and environmental or ES education that helps people to understand the value of nature and increases respect towards local stakeholders (Lundholm 2011).

The distributional equity procedures in ES governance themes addressed in this study relate to managing trade-offs and mitigating negative social and environmental impacts (Briner et al. 2013, Howe et al. 2014); promoting balanced and locally beneficial multi-functional land use (O'Farrell \& Anderson 2010, Gustafsson et al. 2012); introducing marketbased instruments to provide income, incentives or subsidies for local stakeholders (Corbera et al. 2007, Pascual et al. 2014); and using scientific approaches for enhanced cost-benefit analysis of governance options (Wegner \& Pascual 2011).

Procedural and distributional equities both link to regulatory and market-based governance. Here we propose that these dimensions (Table 1) should be looked at simultaneously. Such a proposition is informed by suggestions that ES governance systems should be formed of 'policy mixes', consisting of both regulatory and market-based governance (Howlett \& Rayner 2007, Ring \& Schröter-Schlaack 2011) and the view that procedural and distributional equities are both important objectives of ES governance (McDermott et al. 2013, Pascual et al. 2014). An integrated focus is important because single instruments (regulatory or market-based) with narrow focus may lead to governance failures (Berkes \& Folke 1998, Sarkki et al. 2015b), and because normative calls for 
Table 1. Six subfields of literature addressing procedural and distributional equity of regulatory and market-based governance. PES: payments for ecosystem services.

\begin{tabular}{|c|c|c|}
\hline Focus & Regulatory governance & Market-based governance \\
\hline Procedural equity & $\begin{array}{l}\text { Stakeholder participation (Webler 1995, } \\
\text { Beierle \& Cayford 2002, Reed 2008) }\end{array}$ & PES and procedural equity (Farrell 2014) \\
\hline Distributional equity & $\begin{array}{l}\text { Environmental justice (Walker 2007, } \\
\text { Schlosberg 2007, Ageyman et al. 2003) }\end{array}$ & $\begin{array}{l}\text { PES and distributional equity (Corbera 2012, } \\
\text { Wunder 2013, Lakerveld et al. 2015) }\end{array}$ \\
\hline Combined focus & $\begin{array}{l}\text { Social sustainability (Gibson 2006, } \\
\text { Puhakka et al. 2009) }\end{array}$ & $\begin{array}{l}\text { Social dimensions of ES governance } \\
\text { (Corbera et al. 2007, Pascual et al. 2014) }\end{array}$ \\
\hline
\end{tabular}

social sustainability address both governance processes and distributional outcomes (Puhakka et al. 2009). In this study we use the literature (from this subsection and Table 1) on environmental and ES governance to inform our specific treeline area case studies, and set out detailed proposals on how treeline governance may be enhanced to meet these general challenges.

\subsection{Knowledge gaps and objectives}

The first theoretical gap we identified is that the quality of ES governance has been studied primarily by focusing on distributional equity of market-based instruments, such as payments for ecosystem services (PES) (e.g. Wunder 2013). The reason that ES literature focuses more on distributional than procedural equity reflects the prevalent ecological economics perspective, for which distributional equity is of key concern (Farrell 2014). However, the equity implications of ES governance also need to be evaluated 'in terms of access to the processes of defining which services should be conserved' (Farrell 2014, p. 138), which is often neglected in ES literature (Petheram \& Campbell 2010). Furthermore, the social equity of regulatory ES governance needs to be examined and recognized as an important issue to a greater extent than in current ES literature (Primmer et al. 2015). Regulatory governance has been neglected in ES research, perhaps due to the strong focus on market-based PES (Wunder 2013).

This study examines procedural and distributional equity of ES governance in European treeline areas. A treeline can be defined as the forest boundary/ transition zone (Armand 1992). However, treeline area is here not strictly defined as an ecotone; we used a broader definition that better fits to our research question. We focus on 'treeline-related administrative areas and associated landscapes and ecosystems' (Sarkki et al. 2015a). Treeline areas are important indicators of social-ecological change because they are heavily affected by various drivers, in particular by relating to climate change and land use. Impacts of these drivers include land abandonment and the reforestation of formerly treeless areas (Huber et al. 2013). In addition, there is need for improved governance, as the balanced use of ESs in treeline areas can provide a range of benefits for multiple stakeholders (Grêt-Regamey et al. 2012).

Analysis of treeline ESs has been done for smaller areas around the treeline or for certain ESs in mountainous regions (e.g. Grabherr 2009, Hastik et al. 2015), but there are few Europe-wide mappings of ESs combined with stakeholder and governance analysis. Sarkki et al. (2015a) identified key ESs in European treeline areas and found that activities of stakeholders are very context-specific; this study also identified a lack of governance structures to adequately address the particular characteristics of these areas. A similar finding relating to the insufficiency of current public and private governance systems for the implementation of multifunctional forest management in different mountain regions in Europe is reported by Sarvašová et al. (2014). However, these studies do not synthesize challenges and proposals to enhance the social equity of ES governance in European treeline areas. In this study we start to fill this gap by examining 11 case studies in European treeline areas and develop a set of empirically grounded and conceptually clustered proposals on how social equity could be enhanced in the governance of treeline ESs.

The overall objectives of this study are (1) to analyze the procedural and distributional equity of ES governance in European treeline areas, and (2) to develop proposals on how procedural and distributional equity can be enhanced separately and in combination. This provides added value to ES governance literature by connecting sets of conceptual themes identified in case studies; these are drawn together into five more general proposals on how social equity of ES governance can be enhanced. 


\section{MATERIALS AND METHODS}

We examined the issues of procedural and distributional equity in ES use by analyzing 11 cases of European treeline areas from 8 countries (Fig. 1). The case studies represent different types of treeline areas found in Europe, including mountainous arctic treeline areas (latitudinal treeline) in Northern Europe, open moorlands in Western Europe, and mountain rangeland (altitudinal treeline) in Southeastern and Eastern Europe (Table 2).

The EU-funded SENSFOR COST-Action (ES1203: Enhancing the resilience capacity of sensitive mountain forest ecosystems under environmental change) is a networking project integrating natural and social scientists to compare and synthetize knowledge relevant for the resilience and sustainability of European treeline areas. It has 198 participants from 23 EU countries and from Ukraine. In addition to members of the Management Committee, the core group and working groups, participants include students that take part in SENSFOR training schools and researchers who conduct short term scientific missions as part of the COST-Action. The case study descriptions were collected in response to an open call sent to members of the SENSFOR consortium (www.sensforcost.eu/). The responses to the call determined the selection of case studies; however, these provide a good representation of the different types of treeline areas in Europe (Fig. 1). The members of the SENSFOR consortium are experts in treeline area dynamics occurring at different sites in Europe. The call identified specific themes to which the case study authors should provide answers, in order to standardize the reporting. We realize that the case study authors have different kinds of expertise related to their case studies and the quality of the case study may depend on the methods used in each case study. However, we assume that only researchers with sufficient knowledge on their cases regarding the specific themes responded to this call. This also explains the relatively low response rate (around 10\%). The themes considered in the case descriptions included basic information about the area's governance instruments in use, relevant ESs and related problems in the area, descriptions of good or bad governance practices, and lessons learned in terms of proposals to enhance good governance practices. The case descriptions are 4 to 5 pages long and published in full online (SENSFOR Deliverable 4, www.sensfor cost.eu/images/Deliverable\%204.pdf). The present study is a joint effort of the SENSFOR consortium; therefore all the case study authors are included as co-authors in this study, even though the first author is responsible for the analysis, interpretations and conclusions.

We used inductive content analysis, a structured assessment method that is useful when existing theory or data are limited or fragmented (Hsieh \& Shannon 2005). In contrast to deductive content analysis, the concepts are not derived from theory, but built from the empirical materials. This requires careful analysis of the materials provided by the case studies

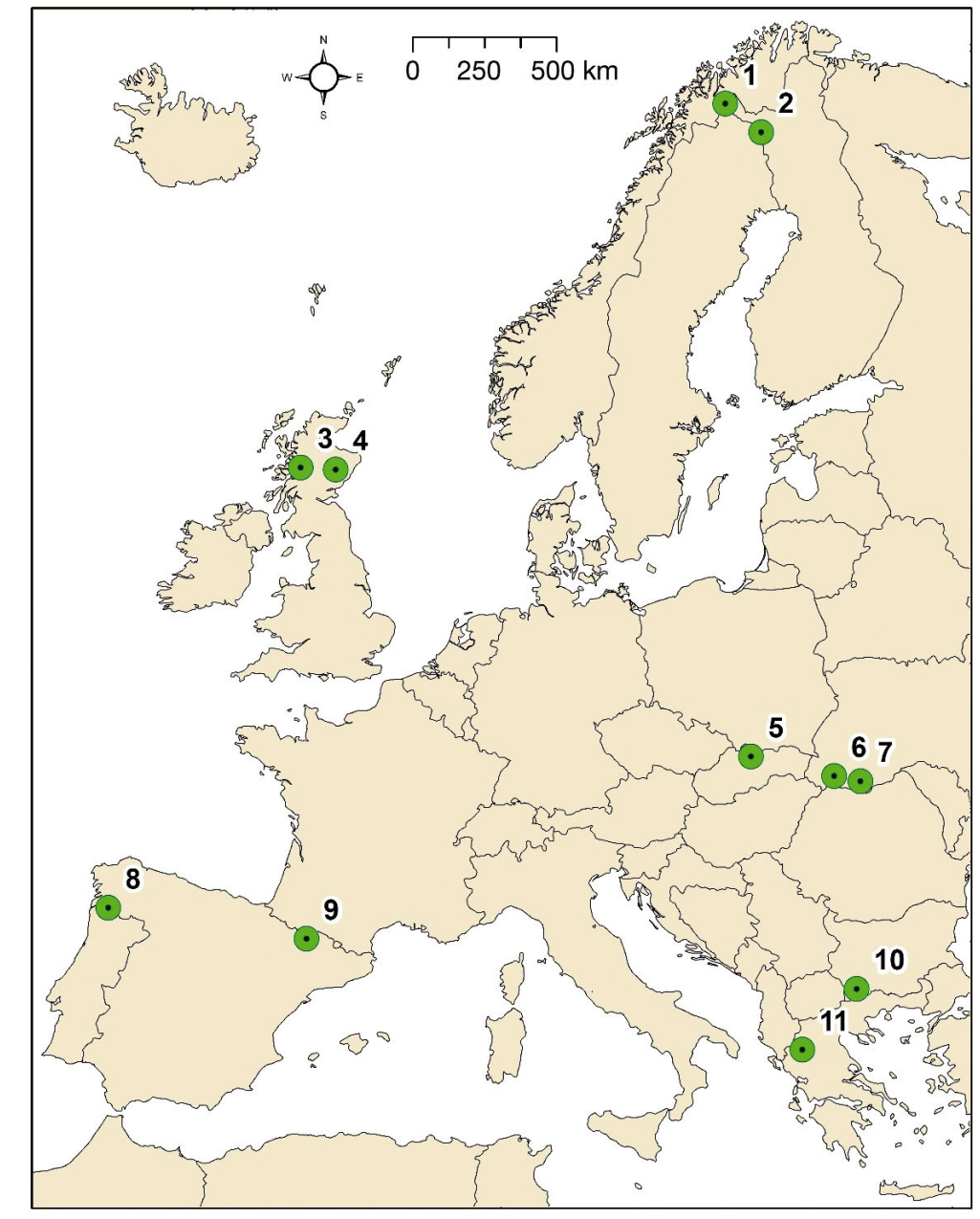

Fig. 1. Map of the case study areas used for a review of governance of ecosystem services (ES) in European treeline areas. See Table 2 for names of case study areas 
Table 2. Case study areas, methods to collect empirical materials and key stakeholder groups. The numbers in the second column corresponds with the numbered locations on the map (Fig. 1) and numbered references to case studies in the text. ES: ecosystem services

\begin{tabular}{|c|c|c|c|c|}
\hline Case study area & No. & $\begin{array}{l}\text { Size } \\
\left(\mathrm{km}^{2}\right)\end{array}$ & Empirical methods & Key ES users / stakeholders \\
\hline $\begin{array}{l}\text { Kilpisjärvi, } \\
\text { NW Finnish Lapland }\end{array}$ & 1 & 500 & $\begin{array}{l}\text { Questionnaires for stakeholders; } \\
\text { stakeholder interviews; analysis of } \\
\text { management and planning } \\
\text { documents; media follow-up; } \\
\text { stakeholder workshops; participation } \\
\text { in land-use planning meetings }\end{array}$ & $\begin{array}{l}\text { Reindeer herders; nature-based } \\
\text { tourism entrepreneurs; protected area } \\
\text { management officials; scientists in } \\
\text { local research station }\end{array}$ \\
\hline $\begin{array}{l}\text { Muonio, } \\
\text { NW Finnish Lapland }\end{array}$ & 2 & 200 & $\begin{array}{l}\text { Stakeholder interviews; analysis of } \\
\text { management and planning documents; } \\
\text { media follow-up }\end{array}$ & $\begin{array}{l}\text { Tourism entrepreneurs state forestry } \\
\text { enterprise; reindeer herders; local } \\
\text { environmental NGO; Hunters; local } \\
\text { residents }\end{array}$ \\
\hline $\begin{array}{l}\text { Lochaber Forest District, } \\
\text { NW Scotland }\end{array}$ & 3 & 5000 & $\begin{array}{l}\text { Analysis of management and planning } \\
\text { documents; ecosystem services map- } \\
\text { ping and modelling; ecological field data } \\
\text { collection; stakeholder workshops }\end{array}$ & $\begin{array}{l}\text { Forestry enterprises; pastoralists } \\
\text { (sheep and cattle) }\end{array}$ \\
\hline $\begin{array}{l}\text { Moray and Aberdeenshire } \\
\text { Forest District and the Dee } \\
\text { Catchment, NE Scotland }\end{array}$ & 4 & 11000 & $\begin{array}{l}\text { Analysis of management and planning } \\
\text { documents; stakeholder interviews; } \\
\text { stakeholder workshops }\end{array}$ & $\begin{array}{l}\text { Forestry enterprises; protected area } \\
\text { management officials; local residents; } \\
\text { nature-based tourism entrepreneurs }\end{array}$ \\
\hline $\begin{array}{l}\text { Tatra National Park, } \\
\text { Dolina Parichvost Valley, } \\
\text { Slovakia }\end{array}$ & 5 & 740 & $\begin{array}{l}\text { Analysis of management and planning } \\
\text { documents; valuation studies on the } \\
\text { economic impacts of restrictions posed } \\
\text { by nature conservation }\end{array}$ & $\begin{array}{l}\text { Forestry enterprises; private forest } \\
\text { owners; protected area officials; } \\
\text { hunters; nature-based tourism } \\
\text { entrepreneurs }\end{array}$ \\
\hline $\begin{array}{l}\text { Villages Nyzhniy Bystry } \\
\text { (Khust region) and } \\
\text { Bohdan (Rachiv region) } \\
\text { in the Carpathian } \\
\text { Mountains, Ukraine }\end{array}$ & 6 & 110 & $\begin{array}{l}\text { Active involvement in participatory } \\
\text { Community Development Plan; } \\
\text { questionnaires and surveys for stake- } \\
\text { holders; analysis of management and } \\
\text { planning documents }\end{array}$ & $\begin{array}{l}\text { State forestry enterprise; pastoralists } \\
\text { (cattle and sheep grazing); nature- } \\
\text { based tourism entrepreneurs; local } \\
\text { residents }\end{array}$ \\
\hline $\begin{array}{l}\text { Lviv Chernivtsi and } \\
\text { Ivano-Frankivsk regions } \\
\text { in the Carpathian } \\
\text { Mountains, Ukraine }\end{array}$ & 7 & 24000 & $\begin{array}{l}\text { Stakeholder workshops; media } \\
\text { follow-up }\end{array}$ & $\begin{array}{l}\text { State forestry enterprise; nature-based } \\
\text { tourism entrepreneurs; local residents; } \\
\text { hydropower enterprises }\end{array}$ \\
\hline $\begin{array}{l}\text { Peneda do Gerês } \\
\text { National Park, Portugal }\end{array}$ & 8 & 700 & $\begin{array}{l}\text { Long term ecological investigations } \\
\text { with in situ and satellite data } \\
\text { (Landsat; Worldview-2); stakeholder } \\
\text { interviews; stakeholder workshops }\end{array}$ & $\begin{array}{l}\text { Protected area management officials; } \\
\text { pastoralists (cattle and sheep); } \\
\text { farmers; nature-based tourism } \\
\text { entrepreneurs; local residents }\end{array}$ \\
\hline Central Pyrenees, Spain & 9 & 1380 & $\begin{array}{l}\text { Stakeholder interviews; vegetation } \\
\text { maps; statistics regarding trends in } \\
\text { human population and livestock }\end{array}$ & $\begin{array}{l}\text { Tourism entrepreneurs (ski and } \\
\text { nature-based tourism); pastoralists } \\
\text { (sheep and cattle); local residents }\end{array}$ \\
\hline $\begin{array}{l}\text { Pirin National Park, } \\
\text { SW Bulgaria }\end{array}$ & 10 & 400 & $\begin{array}{l}\text { Long term ecological investigations } \\
\text { and mapping; stakeholder interviews; } \\
\text { stakeholder workshops; analysis of } \\
\text { management and planning documents }\end{array}$ & $\begin{array}{l}\text { Protected area management officials; } \\
\text { tourism entrepreneurs (especially } \\
\text { skiing resorts); mountain agriculture }\end{array}$ \\
\hline $\begin{array}{l}\text { Northern Pindos National } \\
\text { Park, Greece }\end{array}$ & 11 & 2000 & $\begin{array}{l}\text { Analysis of management and planning } \\
\text { documents; ecological monitoring } \\
\text { and data collection; active involvement } \\
\text { in participatory development plan } \\
\text { on information and awareness }\end{array}$ & $\begin{array}{l}\text { Forestry enterprises; pastoralists; } \\
\text { protected area management officials; } \\
\text { nature-based tourism entrepreneurs }\end{array}$ \\
\hline
\end{tabular}


to identify statements relevant to the research question. These individual statements are then compared across the material and content clusters with similar insights are defined. Descriptive titles for the content clusters are then created. Finally, all the clusters are checked to ensure that all the similar issues are clustered under the same titles. This ensures that empirically derived concepts (titles) relevant to each research question can be identified (Elo \& Kyngäs 2008). This method does not require the compared cases to be based on the same research methods. Instead, diversity within the researched themes is a strength from which qualitative conclusions can be extrapolated (Hsieh \& Shannon 2005).

In this study, the inductive content analysis was conducted accordingly: (1) We extracted the problems related to the use of ESs (Section 3.1) directly from case study descriptions (see Table 3). (2) The proposals for enhancing social equity of ES governance were identified by clustering proposals for good governance from the 'lessons learned' section of the case study descriptions. In total, 75 proposals were identified by the case descriptions. (3) These proposals were clustered under 10 titles identifying factors of importance for the equity of ES governance in European treeline areas. The titles were either procedural equity-related (6 clusters; see Section 3.2) or distributional equity-related (4 clusters; see Section 3.3). Thus, the proposals to enhance social equity of ES governance are based on a synthesis of the results from the 11 case studies. However, not every proposal is relevant to every case. Therefore, when considering the generalizability of the findings, it should be noted that it is very unlikely that each proposal would be relevant for single future case studies. However, as this is a synthesis of many cases, the proposals represent an important collection of issues relevant for social equity of ES governance. Furthermore, the Discussion connects the findings to existing governance literature in order to enhance the generalizability of the gained conclusions.

\section{RESULTS}

\subsection{Challenges for ES governance}

The ES associated with treeline areas are under multiple pressures, including issues related to climate change and land-use governance (Table 3).

The pressures we identified (Table 3) for the sustainable delivery of ES in European treeline areas are linked to land-use and climate change, highlight- ing the importance of these issues. Plausible climate change impacts on treeline areas relate to 3 broad climatological trends: (1) rising temperature, which may increase fire occurrence, shift the treeline to higher elevations, and reduce the number of days with sufficient snow cover for skiing resorts; (2) changes in precipitation, including increased occurrence of droughts, that affect grazing lands and water flow; (3) increased occurrence extreme events that affect treeline areas, for example, by increasing windthrow.

Most of the assessed treeline areas include protected areas, which are governed by regulatory instruments, while market-based instruments are scarcer in case studies reviewed. In many cases, NGOs and local communities have initiated self-organized pressure campaigns to influence land-use decision making in treeline areas (case studies 2, 7, 5, 10; note that here and henceforth, case study numbers are denoted in square brackets). This highlights the fact that existing governance instruments in treeline areas do not satisfy all stakeholders. Identified problems for social equity in the case studies included problems in transparency, technocratic management paradigms focusing on a single resource or sector, multi-level interactions that do not recognize local land-use rights, and loss of pastures and ecological degradation and their impacts on local livelihoods. Therefore, to enhance social equity of ES governance in treeline areas, carefully designed policy mixes combining regulatory and market-based instruments are needed.

\subsection{Proposals to enhance procedural equity}

The proposals to enhance procedural equity can be grouped into 6 themes.

\subsubsection{Stakeholder collaboration and negotiation}

The most frequently identified theme regarding proposals to enhance procedural equity was the requirement to enhance multi-stakeholder collaboration. In practice this could mean, for example, authorities utilizing local consultative committees and scientific advisors in order to moderate divergent views and provide inputs for management. Here agencies responsible for implementing other governance instruments should be accountable to the local forums in order to move from discussions to effective decisions, and scientific advisors should also consider 
Table 3. Pressures on the environment and ES in the case study areas. See Table 2 for names of case study areas. ES: ecosystem services

\author{
Case Pressures on the environment \\ study and ES \\ no. \\ $1 \quad$ Climate change; reindeer overgrazing / \\ absence of reindeer grazing; potential mining; \\ increasing insect attacks in a warming climate; \\ increasing pressure from tourism \\ 2 Potential industrial logging in adjacent areas \\ of the National Park
}

3 Potential increase of logging; climate change; pests and diseases; changing markets; tree breeding

$4 \quad$ Potential increase of logging; infrastructure development; building renewable energy facilities and their demand for raw material (e.g. wood); increasing access to treeline areas by tourists; spread of invasive species and climate change

$5 \quad$ Industrial logging

6 Current forest management favouring industrial logging

7 Potential construction of several hundred hydroelectric power plants (HPPs) changing hydrology and decreasing recreational and cultural values

8 Fire occurrence regime and intensity of fire; farmland abandonment

$9 \quad$ Uncontrolled construction of buildings and infrastructure for skiing tourism; continuous decline in grazing activity; land abandonment

10 Climate change (warming); enlargement of winter tourism activities (ski-slope facilities); changes in natural vegetation and water flowing systems

11 Conflict between viable bear population, supported by the National Park and NGOs, and livestock farmers
Governance instruments addressed

by the case studies

Protected area management planning; municipal land use planning; regulations to set maximum allowed number of reindeer

State agency-led forestry planning; pilot implementation of payment for ecosystem services (PES) to manage land use conflict; National Park management planning

National Land Use Strategy; Scottish Forestry Strategy; UK Forestry Standard (comprising legal requirements, guidance for managers and standards for regulation and monitoring)

Forest District Plan; The Indicative Forest and Woodland strategies that are annexed to Local Development and Strategic Plans (the main local and sub-regional spatial and land-use planning instruments in Scotland)

Forest management plans; compensation mechanisms for forest owners who refrain from logging; game management plans

Regional state-led forest planning including collaborative community development plans; the area is next to the UNESCO Carpathian World Heritage Site and Biosphere Reserve

Regional state led forest planning; European investment support for HPPs; cost-benefit analysis and strategic impact assessment of HPPs by investors; ad hoc management committees to assess impacts of HPPs; scientific advisory body

National Park management planning; EU Common Agricultural Policy (CAP) and European Regional Development Fund (ERDF), scientific advisory body

Regulatory and financial aspects of CAP; protected area management plans; natural resources management plans; scientific advisory body

National Park Management Plan; UNESCO World Heritage Site

Regional land use management; brown bear conservation plans; NATURA 2000

4, 7, 11]. (2) Collaboration creates space for finding balanced solutions for multi-functional land use and gives rise to new partnerships that strengthen the positions of marginalized stakeholders, helping them to negotiate governance solutions [4]. (3) Governance decisions gain legitimacy and the increased

knowledge base can be used, for example, to man- local knowledge $[1,6,10)]$. The following benefits of collaboration for social equity were proposed: (1) Collaboration creates better understanding of the problem as defined by treeline stakeholders, bringing divergent local attitudes and cultural values into governance discussions; 'planning for people with people' gives rise to shared visions for governance [1, 
age risks (e.g. wild fires, impacts of land use and land abandonment on grazing lands and mountain ecology) through multi-stakeholder collaboration [8, 9]. (4) Stakeholders with various backgrounds, including indigenous people and local pastoralists, could feel more comfortable joining in governance discussions if such discussions use more culturally sensitive procedures (e.g. multiple methods to ensure respectful and fair discussions, unbiased facilitation of meetings by a neutral facilitator from a neutral organization, and choosing appropriate locations for the meetings) [1].

Problems regarding bottom-up collaboration were also identified, including a dislike of restrictive rules by local actors and the unwillingness of governance authorities to collaborate because they feared that environmental sustainability would be compromised by local participation [6,8]. Problems could include communication breakdowns between governance officials and multiple local stakeholders, and nonneutral stakeholder-led planning $[1,2]$.

\subsubsection{Balanced interaction between vertical and horizontal governance levels}

Two case studies stressed that decision making should use a more integrated multi-level approach, whereby top-down hierarchies would be replaced by balanced 2-way effects and feedback systems [4, 5]. It was highlighted that the implementation of governance decisions at higher levels may actually break down local structures. Thus, local and traditional tenure rights to use treeline ES (e.g. grazing practices, use of wood) should be respected by the higher level governance decisions [4]. Currently, there are also international agreements and standards that aim to safeguard traditional values and ways of life, such as the Akwé-Kon guidelines in the Convention of Biological Diversity that aim to secure local and indigenous rights in protected areas. However, it is debatable how well Akwé-Kon guidelines are taken into account in concrete local land-use planning decisions [1]. It is also unclear how well international and state level environmental policy priorities that recognize local rights are transferred to local level decisions [5]. Moreover, international policies may have adverse effects at the local level. For example, the EU's Common Agricultural Policy has led to intensification of cattle farming and reduction of sheep farming, leading to abandonment of previously utilized pastures and agriculture fields in treeline areas. This changes treeline ecological condi- tions by increasing shrub encroachment in the remaining grazing lands [9].

\subsubsection{Increased environmental and ES education}

Many of the examined case studies highlighted the fact that long-term environmental and ES education could also contribute to good governance. ES education could be facilitated for example by protected area managements, public information campaigns, and integrated as parts of various land use planning governance instruments. Decision makers and NGOs understand or are obliged to respect environmental values, but it was suggested that increasing efforts should be directed towards the wider public so that they can better understand the significance of the multiple benefits provided by the environment $[5,6]$. Thus, lack of acceptance of governance measures by local actors could be remedied through ES education. For example, in Greece exclusionary management of large carnivores, which can be detrimental for pastoralists, has been replaced by campaigns promoting human-bear coexistence, increasing local acceptance towards presence of the bears. This has been done by communicating the benefits of viable bear populations for tourism and also through development of local, certified bear-friendly products [11]. It was also suggested that governance officials should be educated to better understand stakeholders' motivations and values. Such education could help in conflict mediation $[1,4]$. Finally, education on how governance systems work and how local people can have an effect on them could enhance selforganization capabilities of marginalized local people $[2,6]$.

\subsubsection{The role of science in governance}

Using science and including stakeholders as legitimate providers of scientific knowledge were highlighted as important components of good ES governance. They can be promoted using transdisciplinary projects involving collaboration between local people (e.g. pastoralists), researchers and governance officials [4, 9]. Ecological knowledge could be used to define environmental carrying capacity and the limits of acceptable change. Such knowledge could be used, for example, to define the maximum number of national park visitors [10]. However, this could further marginalize local people by imposing restrictions for pastoralism, justified by its negative impacts 
on ecological integrity [1]. Cost-benefit analysis can also be used in governance to define the amount of compensation paid to local forest owners due to logging restrictions $[5,7]$. Furthermore, planning processes could utilize multiple social science techniques (e.g. interviews, surveys, workshops) in order to generate more culturally sensitive approaches that acknowledge local concerns $[1,6]$.

\subsubsection{Early phase collaboration}

Early phase and iterative collaboration is important to gain an in-depth understanding of stakeholders' concerns and values. These may remain unrecognized, or could even be misinterpreted, when 'oneshot' participation approaches are applied [2, 6, 11]. Long-term collaboration provides a setting for understanding the values and objectives of other stakeholders; the resulting increased sensitivity towards local people's every day concerns could help to alleviate or prevent conflicts $[1,4]$. Early phase collaboration is preferable to the presentation of readymade plans to local people that can easily polarize opinions for and against an issue. With instrumental one-shot collaboration approaches, finding a consensual space is more difficult $[2,6,7]$. Building compromises between conflicting views is time consuming 'hard work', and thus governance officials 'should be smart and persistent' when implementing collaborative structures [2, 6]. Furthermore, long-term collaboration could help to break path dependency related to the focus on single resources, such as technocratic maximization of wood production, as opposed to objectives for multifunctional use of ESs $[2,6]$.

\subsubsection{Transparency and openness}

Transparency was stressed in some case studies $[1,2,11]$ as a key to enhance relationships between local stakeholders and governance officials. When local people understand that conservation may also have positive effects for local development, the potential for local acceptance of decisions and synergies between locals and protected area officials increases [11]. On the other hand, a lack of transparency by governance officials may evoke resistance and cause conflicts when locals find out about the plans, such as logging in areas important for local economic, subsistence and recreation activities. Increased transparency decreases the likelihood of open conflicts, or at least helps build trust between local people and governance officials. Trust between locals and governance officials also increases the capacity for future collaboration and for achieving common visions for ES governance [1, 2].

\subsection{Proposals to enhance distributional equity}

The proposals to enhance distributional equity can be grouped into 4 themes.

\subsubsection{Mitigation of negative social and environ- mental impacts}

The case studies provided the following suggestions to enhance mitigation of negative social and environmental impacts. Firstly, traditional livestock management practices, including use of guard dogs, can prevent threats to livestock by bears, as highlighted by case study from Greece. Reactivation of previously used local practices can be supported by pilot projects funded (for example) by the EU. Without active measures, the burdens of bear conservation are placed on local people. Therefore, conservation governance needs to promote affirmative actions to enhance social equity and sustain and enable local livelihoods [11]. Secondly, protected area zoning can provide benefits both for ecological sustainability and local people by creating strictly protected core zones and allowing human activities in other less protected zones. Pirin National Park in Bulgaria has also used buffer zones to mitigate negative effects of visitors on the park. This park is a World Heritage Site, which has built a reputation, functions as an attraction for tourists, and encourages governance officials to work to retain this status. This strengthens the local economy and ensures ecological sustainability [10]. Thirdly, the potential negative impacts of forestry practices on ecosystems and ESs can be mitigated using 'softer' logging methods. Forestry practices favoring uneven-aged forests are often perceived as beneficial for local stakeholders because they enable alternative uses of ES in forest areas (e.g. ecotourism; grazing, recreation, local use of nonwood forest products, hunting) $[2,6]$.

\subsubsection{Research on ESs to identify alternative goals for governance}

Some of the case studies illustrated the fact that ES assessments provide legitimate and credible ways of 
combining local needs with national level policy targets. For example, the Scottish Government's woodland expansion targets were able to be met by balancing stakeholder's demands on treeline ES with enviornmental objectives taking into account alternative land use types. Such assessments provide a basis for the identification of synergies and trade-offs resulting from a certain land-use type and between local actors and national, high-level policy objectives. This can lead to an increased recognition of local demand for ESs and also of the ways that certain local land use practices enhance ESs for other stakeholders $[3,4]$. On the other hand, governance instruments could be developed to capture values linked to ESs in order to enhance the social equity of ES governance. For example, identifying the synergy between local practices and environmental values can be used to promote local products, using labelling to increase income for local producers [11]. Furthermore, local stakeholders often consider that cultural ESs can provide a steady income and constant flow of services and related benefits, as opposed to one-off intensive utilization of provisioning services. Therefore, ES assessments of the values of, for example, forest-related cultural ESs can justify alternative governance arrangements for industrial forestry that also promote social equity of ES governance $[2,6,8]$. ES assessments can also identify otherwise unrecognized regulation and maintenance ESs (e.g. water cycling, down-stream services) that benefit local people, but often remain unacknowledged by governance instruments [6].

\subsubsection{Multi-functional land use}

Governance should actively seek options that enhance multi-functionality, and win-win solutions [2, $6,10,11]$. However, powerful groups may be able to efficiently oppose options that would benefit the other stakeholders. This is especially the case where robust governance regimes have been dominated for decades by state organizations that see national benefits from (for example) forestry as more important than local demands for ESs [2,7]. Furthermore, in some cases European and national policies (e.g. CAP) have aimed to promote diverse rural land use, but have actually contributed through targeted incentives to the growth of tourism at the expense of agriculture, leading to land abandonment [9]. It is true that tourism provides a valuable income for treeline area stakeholders. However, rapid growth of tourism leads not only to an intensified use of nature but also, interestingly, to unequal social effects including a strong decline in the social position of those local stakeholders not engaged in tourism businesses. Therefore, active governance measures are needed to balance distribution of benefits and burdens of tourism for local actors, for example by diversifying tourism products and services [10]. On the other hand, despite the abovementioned potential for ES assessments to address the issue of social equity, the governance officials and scientists involved may have divergent views on how governance measures should be implemented in practice. This can relate to decisions on how to regulate local traditional pastoral practices, which are often seen as a threat to environmental values. However, such a position neglects the fact that active pastoralism may also help produce ESs (e.g. supporting some species over others, continuing traditional cultural practices that function as a tourism attraction, producing local high quality meat and dairy products, mitigating shrub encroachment) $[1,9]$. Thus, even though protected area governance targets environmental values, it should not exclude local people, but rather see them as integral part of the social-ecological system that it intends to protect and sustain $[9,11]$.

\subsubsection{Market-based instruments to balance benefits and burdens}

Innovative public payment schemes provided by government may be used to complement regulatory governance and support sustainable use of ESs [4]. However, subsidies and compensation may not be strong enough to change unwanted trends. For example, in the Pyrenees the CAP and other agricultural policies have provided subsidies for local people to inhabit villages near treeline areas, but nevertheless, the numbers of people practicing agriculture or pastoralism in rural areas keep declining. Thus, subsidies may be ineffective in addressing the challenges they aim to address. Such ineffectiveness may be caused by lack of resources, and thus prioritization is needed. Hence, consensual criteria defined with the participation of local people for the prioritization of needs for subsidies could be established to mitigate contradictions that may arise when subsidies are felt to function in an unjust manner [9]. Another potential solution for implementation by governance actors is to conduct a holistic assessment of the costs and benefits of implementing a marketbased approach. Such an assessment could attract responsible investment by showing the potential to 
generate profit by sustainable means. For example in the Ukraine hydroelectric power plants receive subsidies, but may produce burdens for 'downstream' and other treeline area stakeholders. Therefore, cost-benefit analyses and subsidies should not be based solely on environmental assessments, but should also consider social impacts [7]. Reliable holistic assessment of the costs and benefits of an investment, incentive or subsidy may be challenging, due to the complex spatial distribution of benefits and burdens. Therefore, incentive schemes should target land owners and managers in a spatially explicit way, and also take account of benefits and burdens for stakeholders at various levels, especially at the local level, in order to enhance social equity [3].

\section{DISCUSSION}

Proposal 1. Procedural equity underpins distributional equity by defining those who can influence decisions that have material outcomes.

The ES literature has identified ES-related distributional synergies and trade-offs as one key area of investigation (Howe et al. 2014, Briner et al. 2013). Thus the focus of interest of ES literature is more on distributional equity than on procedural issues (Table 1). Procedural aspects, however, often determine the distributional outcomes by regulating, allowing, restricting and denying specific forms of ES use. Therefore, it was no surprise that the need for enhanced collaboration between stakeholders was identified by many case studies as an important feature in order to enhance the distributional equity of treeline ES governance. On the other hand, the negative distributional impacts of enforcing governance rules (for example in protected areas) may be balanced via policy mixes, for example by including economic compensation in regulatory governance arrangements $([4,5,7,9]$; cf. Howlett \& Rayner 2007, Ring \& Schröter-Schlaack 2011). In practice, collaboration, especially early stage collaboration where there is genuine engagement of treeline area stakeholders ([2, 4, 6, 11]; cf. Reed 2008), is a cross-cutting principle that should be carefully considered when designing any governance instrument.

Proposal 2. Single provisioning services may be manageable from the top down, whereas multi-functional demands for treeline areas create the need for enhanced procedural equity to manage distributional equity of benefits deriving from multiple ESs.

Some case studies $[2,6]$ showed that technocratic state-based forest governance has led to negative im- pacts on local social and cultural values and created opposition (cf. Berkes \& Folke 1998); at the same time, new demands have been raised for alternative uses of treeline forest ESs (cf. Sarkki et al. 2015a). Single provisioning services, like timber, can be more easily and efficiently managed in a top-down manner by national level agencies. However, increased demand for alternative uses of forest ESs calls for more collaborative planning practices (Gustafsson et al. 2012) because of the increased complexity of the system to be managed and multi-level nature of distribution arrangements for multiple ESs $[2,6,9,10$, 11]. Social equity concerns become especially acute when the pursuit of previously legitimate national benefits is challenged by calls for governance to respond to diversified interests of multiple stakeholders; concerns relate especially to the local level, where the negative impacts of ES use are also experienced (Pascual et al. 2014). In practice, the move from technocratic single resource governance to participatory governance of multiple ESs takes place through discussion of ES governance among state-run organizations $[2,6]$, protected area management agencies $[5$, $10,11]$ and, in some cases, scientists [1].

Proposal 3. Distributional equity is also impacted by the use of adjacent areas. These spillover effects can be identified and controlled by enhancing procedural equity through holistic and collaborative planning.

ES literature reveals increasing awareness about what services different parts of ecosystems are producing and how use of adjacent areas impact on each other (Grêt-Regamey et al. 2013). In ES governance schemes, this recognition is reflected in measures to enhance distributional equity, such as participatory land use zoning or plans for multi-functional landscapes that designate areas with differing use and access rights ([10]; cf. O'Farrell \& Anderson 2010). This represents a holistic approach to planning, where environmental values and cultural ESs are also secured by planning the use of adjacent areas, thus controlling spillover effects (Sarkki et al. 2013). Spillover effects need to be identified in a participatory manner to enhance procedural equity and to ensure that relevant issues are recognized [2]. For example, a decrease in the area of pastures due to areas being allocated to other land uses may lead to increased competition and conflict over the use of the remaining pastures among pastoral sub-groups ([1]; cf. Heikkinen et al. 2010) and downstream impacts or cultural services may not be easily detectable ([7]; see Hauck et al. 2013). In practice, those responsible for the implementation of sector-based governance instruments, such as protected area planning, Envi- 
ronmental Impact Assessments, municipal land-use zoning and management plans for single resources (e.g. forestry), should communicate across administrative boundaries in order to identify and acknowledge spillover effects and cumulative impacts, and to gain a holistic understanding of the situation of the treeline area in question.

Proposal 4. Involving ES education as a proactive measure to operationalize procedural equity can change how distributional equity is perceived.

ES education processes diverge from traditional environmental education by addressing sometimes little known ESs, and also by focusing on stakeholders instead of simply on environmental values (Lundholm 2011). ES education can promote procedural equity by equipping stakeholders with knowledge about ESs, their governance, and interactions between local stakeholders and ES use [3,4]. This can significantly impact on how distributive equity is perceived by stakeholders in a number of ways. Firstly, ES education on the role of locally harmful wildlife (e.g. large carnivores) as tourist attractions has led to increased acceptance of the presence of predators among local inhabitants [11]. Secondly, ES education can contribute to better understanding among governance officials and scientists of both positive and negative impacts of traditional subsistence livelihoods on environmental values and ESs [1,9]. The literature contains references to positive and negative impacts of traditional livelihoods (Briner et al. 2013, Wegner \& Pascual 2011), but has failed to stress the importance of conveying these impacts in ES education. Thirdly, when education focuses on how stakeholders can actively take part in ES governance, it enhances selforganization capabilities of local actors $[2,6]$, that is recognized as key for sustainable natural resource management (Ostrom 2010). Finally, ES education should not only target those influenced by governance, but also governance officials, especially with regards to historical rights and the concerns, motivations and values of local stakeholders. This could help in conflict management $\left([1,4]_{i}\right.$ cf. Agrawal \& Gibson 1999, Redpath et al. 2013). In practice, protected area officials could assume responsibility for ES education, directed especially at locals but also at visitors and other relevant stakeholders.

Proposal 5. Higher level governance decisions need to provide a mandate for national, sub-national and local governance officials to enhance procedural equity in concrete planning practice to promote distributional equity at local level.

Impacts of often hierarchical (e.g. EU) policies on local level distributional equity should be identified carefully in order to understand their local impacts. The subsidiary principle employed by the EU emphasizes the need for local-level engagement in governance (Jordan 2000) and is a means to enhance social equity of ES governance $[2,6,7]$. However, the links between the governance levels are sometimes problematic. For example, European regulatory and economic policies have led to a growth in the tourism industry, while at the same time undermining conditions, at a local level, for profitable pastoralism [9]. Thus more coherence among different governance levels is needed (Ostrom 2010, Sarkki et al. 2015b). Such multi-level coordination can be expected to enhance distributional equity $\left([3,4]_{i}\right.$ cf. Howlett \& Rayner 2007). This coherence may be achieved if higher level governance decisions provide a mandate for enhancing social equity at local level ([1]; also Jokinen et al. 2016). However, such mandates provide the basis for, but do not guarantee changes in, local planning practices. For example, local and indigenous rights are often recognized and respected by international agreements and actors (e.g. in the Convention on Biological Diversity, and EU policies and regulations), but this recognition may not be manifested in local environmental governance ([1]; cf. Rauschmayer et al. 2009). In practice international and national mandates need to be available to support local level distributional equity, but their implementation at the local level needs to be assessed and monitored in a participatory manner to enhance procedural equity.

\section{CONCLUSION}

This study has provided recommendations on how procedural and distributional equity of ES governance in European treeline areas can be enhanced separately (Section 3) and together (Section 4). This focus provides an example of how to consider procedural and distributional equity as well as regulatory and market-based governance simultaneously (Table 1). The advantage of an integrated focus is that the governance instruments affecting marginal areas or stakeholder groups can be examined holistically, starting out from consideration of a specific area and its ESs, rather than focusing on a single governance instrument. This approach can inform the design of policy mixes that aim to promote social equity by affirmative actions as an integral part of ES governance. Future assessments of ES governance can be informed by the focus provided by this study in order to identify means to enhance social equity through practical governance measures. 
Acknowledgements. This study has been supported by the ESSEM COST-Action ES1203 'Enhancing the resilience capacity of sensitive mountain forest ecosystems under environmental change' (SENSFOR), and by the Horizon 2020 project 'Social innovation in marginalised rural areas' (SIMRA), carried out under contract number 677622 with funds provided by the European Commission to the James Hutton Institute and the University of Oulu.

\section{LITERATURE CITED}

Agrawal A, Gibson C (1999) Enchantment and disenchantment: the role of community in natural resource conservation. World Dev 27:629-649

Agyeman J, Bullard RD, Evans B (eds) (2003) Just sustainabilities: development in an unequal world. Earthscan, London

Armand AD (1992) Sharp and gradual mountain timberlines as result of species interaction. In: Hansen AJ, di Castri F (eds) Landscape boundaries. Springer, New York, NY, p 360-378.

Beierle TC, Cayford J (2002) Democracy in practice: public participation in environmental decisions. Resources for the Future Press, Washington, DC

Berkes F, Folke C (1998) Linking social and ecological systems for resilience and sustainability. In: Berkes F, Folke C, Colding J (eds) Linking social and ecological systems: management practices and social mechanisms for building resilience. Cambridge University Press, Cambridge, p 1-25.

* Briner S, Huber R, Bebi P, Elkin C, Schmatz DR, GrêtRegamey A (2013) Trade-offs between ecosystem services in a mountain region. Ecol Soc 18(3):35

Corbera E (2012) Problematizing REDD+ as an experiment in payments for ecosystem services. Curr Opin Environ Sustain 4:612-619

Corbera E, Kosoy N, Tuna MM (2007) Equity implications of marketing ecosystem services in protected areas and rural communities: case studies from Meso-America. Glob Environ Change 17:365-380

Elo S, Kyngäs H (2008) The qualitative content analysis process. J Adv Nurs 62:107-115

Farrell KN (2014) Intellectual mercantilism and franchise equity: a critical study of the ecological political economy of international payments for ecosystem services. Ecol Econ 102:137-146

Gibson RB (2006) Beyond the pillars: sustainability assessment as a framework for effective integration of social, economic and ecological considerations in significant decision-making. J Environ Assess Policy Manage 8: 259-280

Gløersen E, Price MF, Borec A, Dax T, Giordano B (2016) Cohesion in mountainous regions of the EU: Research for REGI Committee. Directorate-General for Internal Policies, Policy Department B: Structural and Cohesion Policies, Regional Development. European Parliament, Brussels. www.europarl.europa.eu/RegData/etudes/STUD/2016/ 573420/IPOL_STU(2016)573420_EN.pdf

*Grabherr G (2009) Biodiversity in the high ranges of the Alps: ethnobotanical and climate change perspectives. Glob Environ Change 19:167-172

Grêt-Regamey A, Brunner SH, Kienast F (2012) Mountain ecosystems services: Who cares? Mt Res Dev 32(S1): S23-S34
Grêt-Regamey A, Brunner SH, Altwegg J, Christen M, Bebi $P$ (2013) Integrating expert knowledge into mapping ecosystem services trade-offs for sustainable forest management. Ecol Soc 18(3):34

Gustafsson L, Baker SC, Bauhus J, Beese WJ and others (2012) Retention forestry to maintain multifunctional forests: a world perspective. Bioscience 62:633-645

*Hastik R, Basso S, Geitner C, Haida C and others (2015) Renewable energies and ecosystem service impacts. Renew Sustain Energy Rev 48:608-623

* Hauck J, Görg C, Varjopuro R, Ratamäki O, Jax K (2013) Benefits and limitations of the ecosystem service concept in environmental policy and decision making: some stakeholder perspectives. Environ Sci Policy 25:13-21

*Heikkinen HI, Sarkki S, Jokinen M, Fornander DE (2010) Global area conservation ideals versus the local realities of reindeer herding in northernmost Finland. Int $\mathrm{J}$ Business Globalization 4:110-130

Hofgaard A, Tømmervik H, Rees G, Hanssen F (2013) Latitudinal forest advance in northernmost Norway since the early 20th century. J Biogeogr 40:938-949

* Howe A, Suichb H, Virac B, Mace GM (2014) Creating win-wins from trade-offs? Ecosystem services for human well-being: a meta-analysis of ecosystem service tradeoffs and synergies in the real world. Glob Environ Change 28:263-275

Howlett M, Rayner J (2007) Design principles for policy mixes: cohesion and coherence in 'New Governance Arrangements'. Policy Soc 26:1-18

* Hsieh HF, Shannon SE (2005) Three approaches to qualitative content analysis. Qual Health Res 15:1277-1288

*Huber R, Rigling A, Bebi P, Brand FS and others (2013) Sustainable land use in mountain regions under global change: synthesis across scales and disciplines. Ecol Soc 18(3):36

Jokinen M, Sarkki S, Heikkinen HI (in press) The wellbeing effects of localized multi-level environmental governance: case of Kilpisjärvi. Nordia Geographical Publications Yearbook 2016

Jordan A (2000) The politics of multilevel environmental governance: subsidiarity and environmental policy in the European Union. Environ Plann A 32:1307-1324

Körner C (2012) Alpine treelines: functional ecology of the high elevation tree limits. Springer, Basel

Kullman L, Øberg L (2009) Post-Little Ice Age tree line rise and climate warming in the Swedish Scandes: a landscape ecological perspective. J Ecol 97:415-429

* Lakerveld RP, Lele S, Crane TA, Fortuin KPJ, SpingateBakinski O (2015) The social distribution of provisioning forest ecosystem services: evidence and insights from Odisha India. Ecosyst Serv 14:56-66

Lundholm C (2011) Society's response to environmental challenges: citizenship and the role of knowledge. Factis Pax 5:80-96

MA (Millennium Assessment) (2005) Millennium ecosystem assessment: ecosystem and human well-being. Island Press, Washington, DC

*McDermott M, Mahanty S, Schreckenberg K (2013) Examining equity: a multidimensional framework for assessing equity in payments for ecosystem services. Environ Sci Policy 33:416-427

${ }^{\prime}$ 'Farrell PJ, Anderson PML (2010) Sustainable multifunctional landscapes: a review to implementation. Curr Opin Environ Sustain 2:59-65

* Ostrom E (2010) Polycentric systems for coping with col- 
lective action and global environmental change. Glob Environ Change 20:550-557

Pahl-Wostl C (2009) A conceptual framework for analysing adaptive capacity and multi-level learning processes in resource governance regimes. Glob Environ Change 19: 354-365

Pascual U, Phelps J, Garmendia E, Brown K and others (2014) Social equity matters in payments for ecosystem services. Bioscience 64:1027-1036

Petheram L, Campbell BM (2010) Listening to locals on payment for environmental services. J Environ Manage 91: 1139-1149

Primmer E, Jokinen P, Blicharska M, Barton DN, Bugter R, Potschin M (2015) Governance of ecosystem services: a framework for empirical analysis. Ecosystem Services 16: 158-166

Puhakka R, Sarkki S, Cottrell SP, Siikamäki P (2009) Local discourses and international initiatives: sociocultural sustainability of tourism in Oulanka National Park, Finland. J Sustain Tour 17:529-549

Rauschmayer F, van den Hove S, Koetz T (2009) Participation in EU biodiversity governance: how far beyond rhetoric? Environ Plann C Gov Policy 27:42-58

Redpath SM, Young J, Evely A, Adams WM and others (2013) Understanding and managing conservation conflicts. Trends Ecol Evol 28:100-109

Reed MS (2008) Stakeholder participation for environmental management: a literature review. Biol Conserv 141: 2417-2431

Ring I, Schröte-Schlaack C (eds) (2011) Instrument mixes for biodiversity policies. POLICYMIX Report 2/2011, Helmholtz Centre for Environmental Research - UFZ, Leipzig. http://policymix.nina.no/Portals/policymix/POLICY

Editorial responsibility: Nils Chr. Stenseth, Oslo, Norway
MIX\%20Report_No\%202_2011.pdf (accessed on 30 Dec 2015)

Sarkki S, Heikkinen HI, Karjalainen TP (2013) Sensitivity in transdisciplinary projects: case of reindeer management in northern Finland. Land Use Policy 34:183-192

Sarkki S, Ficko A, Grunewald K, Nijnik M (2015a) Benefits from and threats to European treeline ecosystem services: an exploratory study of stakeholders and governance. Reg Environ Chang 16:2019-2032

Sarkki S, Rantala L, Karjalainen TP (2015b) Fit between conservation instruments and local social systems: cases of co-management and payments for ecosystem services. Change Adapt Socio-Ecol Syst 2:59-78

Sarvašová Z, Cienciala E, Beranová J, Vančo M, Ficko A, Pardos M (2014) Analysis of governance systems applied in multifunctional forest management in selected European mountain regions. For J 60:159-167

Schlosberg D (2007) Defining environmental justice: theories, movements and nature. Oxford University Press, New York, NY

WWalker GP (2007) Environmental justice and the distributional deficit in policy appraisal in the UK. Environ Res Lett 2:045004

Webler T (1995) Right discourse in citizen participation: an evaluative yardstick. In: Renn O, Webler T, Wiedemann $\mathrm{P}$ (eds) Fairness and competence in citizen participation. Kluwer, Dordrecht, p 35-86.

Wegner G, Pascual U (2011) Cost-benefit analysis in the context of ecosystem services for human well-being: a multidisciplinary critique. Glob Environ Change 21: 492-504.

* Wunder S (2013) When payments for environmental services will work for conservation. Conserv Lett 6:230-237

Submitted: April 8, 2016; Accepted: November 3, 2016

Proofs received from author(s): January 22, 2017 